\title{
Özel Sektör Çalışanlarının Demografik Özelliklerine Göre İç Girişimcilik Olguları Arasındaki Farklılıkların Belirlenmesine Dair Bir Saha Araştırması ${ }^{*}$
}
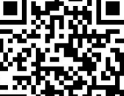

Öz

Bu çalışma, özel sektör çalışanlarının demografik özellikleri dikkate alınarak iç girişimcilik olguları arasındaki farklllıkların belirlenmesi amacıyla hazırlanmış̧ır. İ̧ girişimcilik olgusunu, iç giriş̧imciliği etkileyen bireysel, örgütsel ve çevresel faktörler doğrultusunda incelemeyi amaçlamıştır. Bu amaçla, İstanbul Avrupa yakasında tekstil alanında faaliyet gösteren firmalarda kişisel bilgi formu ve iç girişimcilik ölçeği kullanılarak veriler toplanmıs ve bu veriler SPSS ( Sosyal Bilimler için İstatistik Paketi) 21'de analiz edilmiştir. Hipotez testlerinde normal dağılım varsayımı altında, grup sayısı iki olan kategorik değişkenlerin ölçek puanlarının karşılaş̧tırılmasında bağımsız iki örnek T testi, grup sayısı ikiden fazla olan grupların karşılaştırılmasında tek yönlü anova kullanılmıştır. Daha sonra sonuçlar üzerinde yorum yapılmış ve tartışılmıştır. Araştırmanın sonucunda kurum kapsamında gerçekleştirilen demografik analizlere göre yeni jenerasyonlara ağırlık veren kurumlarda inovatif düşünme tarzına daha yatkın olunduğu ve iç girişimciliğe daha pozitif bir perspektiften bakıldı̆̆ı görülmüştür.
\end{abstract}

Anahtar Kelimeler: İç Girişimcilik, Girişimcilik, Örgütsel Faktörler, Bireysel Faktörler, Demografik Değişkenler.

\section{A Field Study on Determining the Differences Between Internal Entrepreneurship phenomenon by Demographic Characteristics of Private Sector Employees}

\begin{abstract}
This study has been prepared to determine the differences between the internal entrepreneurship cases by considering the demographic characteristics of the private sector employees. The aim of this study is to examine the internal entrepreneurship phenomenon in accordance with the individual, organizational and environmental factors affecting internal entrepreneurship. For this purpose, data were collected by using the personal information form and the internal entrepreneurship scale of the firms operating in the textile field on the European side of Istanbul and these data were analysed in SPSS (Statistical Package for Social Sciences) 21.In the hypothesis tests, two independent sample T tests were used to compare the scale scores of the categorical variables with two group numbers, and one-way ANOVA was used to compare groups with more than two groups under the assumption of normal distribution. The results were then interpreted and discussed. As a result of the research, according to the demographic analysis carried out within the institution, it was seen that institutions that are focusing on new generations are more prone to innovative thinking style and look at internal entrepreneurship from a more positive perspective.
\end{abstract}

Keywords: Internal Entrepreneurship, Entrepreneurship, Organizational Factors, Individual Factors, Demographics.

\footnotetext{
* Bu çalışma İstanbul Aydın Üniversitesi Sosyal Bilimler Enstitüsü İşletme Anabilim Dalı İşletme Yönetimi Programı’nda 25.08.2017 tarihinde tamamlanan "Kurum Kültürü Bağlamında İç Girişimcilik Olgusu ve Bir Uygulama Çalışması” başlıklı yüksek lisans tezinden üretilmiştir.

** Bilim Uzmanı, İstanbul Aydın Üniversitesi, Sosyal Bilimler Enstitüsü, İşletme Anabilim Dalı, İşletme Yönetimi Programı Mezunu. e-mail: ozlembalaman@hotmail.com, ORCID: 0000-0001-9548-3460

*** Dr. Öğr. Üyesi, İstanbul Aydın Üniversitesi, İİBF, Uluslararası Ticaret Bölümü, e-mail: burcinkaplan@aydin.edu.tr ORCID: 0000-0003-4967-8405
} 


\section{Giriş}

İç girişimcilik olgusunu değerlendirmek için öncelikle girişimcilik olgusuna bakılmalıdır. İnsanlık tarihine bakıldığında aslında girişimcilik olgusunun çok eskiye dayandığı görülmektedir. İnsanlık tarihinde dönüm noktasını oluşturan keşif ve icatlar, isimleri bugün bilinmese de bir veya birden çok girişimci bireyin bir araya gelerek oluşturdukları ve yeni bir fikrin hayata geçmesini sağlayan yapılardır. Tekerleğin bulunması, yeni bir inşa tekniği kullanılması, yeni bir tarım tekniği uygulanması hep neticesinde farklı kazanımlar ortaya çıkarmış ve üst üste yaşanan gelişmeler daha farklı yeniliklerin önünü açmıştır. Girişimcilik bu konuda cesaret sahibi, ayırt edici bireylerin özel yetenekleri olabildiği gibi içinde bulunulan şartlar, coğrafya ve kültürel yapı gibi etkenler girişimci bireylerin yetişmesi ve fikirlerini hayata geçirmesi için uygun ortam yaratabilmektedir (Öktem vd., 2003: 171).

Zaman içinde Sanayi Devrimi, iletişim teknolojilerindeki hızlı ilerleme, yeni kaynakların ortaya çıkması, uzmanlıkları gelişmesi büyük şirket yapılarını ortaya çıkarmıştır. Bu şirketler tek uluslu olabildiği gibi çok uluslu da olabilmektedir. Dünya son yüzyılda özellikle büyük şirketlerin yönlendirdiği büyük bir pazar gibidir. Ancak bu dinamik koşulların yok olduğu anlamına gelmez. Büyük dahi olsalar şirketler sürekli kendi yerlerini zorlayan rakiplerle boğuşmak pazarın dinamik taleplerini yenilikçi ürün ve hizmetleriyle karşılamak durumundadır. Aksi durumda bugün ciddi bir rekabet avantajına sahip tekel veya kartel görünümünde bir şirket dahi kısa zamanda diğerlerinin baskısıyla bu avantajını kaybedebilmekte ve rekabette geri düşebilmektedirler (Arıkan, 2002: 29).

İç girişimcilik tam da bu bahsedilen risklerin önüne geçmek amacıyla kurumlar tarafından teşvik edilmekte ve amaca uygun biçimde kullanılmaktadır. Burada önemli olan şirketlerin ağır bürokratik yapılar içinde çalışanların bireysel potansiyellerini atıl tutmamak ve açığa çıkarmaktır. Kurumlar bir birey gibi tek vücut hedefe yönelirken farklı fikirlerin ve uygulamaların getireceği dinamizmi ihmal etmemelidirler. Tek vücut hedefe dönük davranmak güç sağlarken farklılıkları değişik fikirleri ve uygulama taleplerini gözden kaçırmamalıdır.

Yeni ekonomik düzen içinde yer almaya ve öne çıkmaya çalışan ülkelerde serbest girişimin iç girişimcilik yönünde bilgilenmesi bu konuda bizatihi kurumları teşvik edici araştırma ve literatür çalışmalarının yapılması önem arz etmektedir (Öktem vd., 2003: 181).

$\mathrm{Bu}$ çalışmada hedeflenen, özel sektör çalışanlarının demografik özelliklerine göre iç girişimcilik olguları arasındaki farklılıkların belirlenmesidir. Bu amaçla çalışmanın ilerleyen bölümlerine bir saha çalışması ve bu çalışmanın sonuçlarının irdelendiği bulgular ve sonuç bölümü eklenmiştir. Çalışmada literatür kısmı için tarama ve derleme metodu kullanılmıştır. Saha çalışmasında veriler anket yolu ile toplanmış ve gerekli analizler SPSS programı yardımı ile gerçekleştirilmiştir.

\section{2. İç Girişimcilik}

Günümüzde var olan küresel ölçekteki pazar ekonomisi, küresel dünyanın her bölümündeki kurumlarda ve piyasalarda yoğun ve kapsamlı değişimlere yol açabilmektedir. Ortaya çıkacak olan bu değişimler başta kuruluşların hedeflerini itinalı bir şekilde analiz etmelerini ve onları başarılı olma yolunda ilerleten stratejilerini tekrardan koordine etmelerini ve bu stratejileri hayata geçirme aşamasında da büyük özen göstermelerini zorunlu hale getirmektedir. Bugünün organizasyonlarının bu sikı küresel rekabet piyasasında ayakta tutunabilmeleri, "devamlı yenilik ve gelişme" perspektifini içselleştirip bunu kendilerine temel belirlemeleri ile alakalıdır. Bu sebeple, birçok araştırmacı ve akademisyen potansiyel kuruluşlar bünyesinde iş görenlere 
daha derin bir özerklik (otonomi), hürriyet ve kaynak kullanma olanağı sağlayan ve yaratıcı perspektiflerinden yararlanarak yenilikler ortaya koymalarına yarayan bir sistem olmak üzere “iç girişimciliği”" önermektedirler (Kuratko ve Hodgetts, 2001:51-52).

Başta Amerika Birleşik Devletleri ekonomisi üzerinde değerli bir kuvvet olmak üzere ele alınan modern girişimcilik atağının, girişimcilik uygulamalarının organizasyonların bünyesinde de ortaya çıkarılması talebinin meydana gelmesine kaynak olduğu savunulmaktadır. Birtakım araştırmacıların girişimcilik yönelimi ile organizasyonların tabii bulundukları bürokratik düzenlerin birbirlerini dışta bırakan ve beraber varlıklarını sürdürmeleri olası bulunmayan uygulamalar olduğu durumunu ortaya atmalarına karşın, diğer bir taraftan birçok araştırmacıysa girişimciliği ve girişimsel uygulamaları organizasyon mertebesinde değerlendirerek açıklamaya çabalamışlardır. Bu hususta birçok kurumda başarılı olmuş iç girişimcilik uygulamaları mevcuttur.

İç girişimcilik kapsayıcılık ve hareket alanı olarak girişimcilikten daha dar bir alanda hareket etmektedir. Bu hali onu kendi içyapısında daha özellikli kılmaktadır. Genel anlamıyla girişimcilik ile iç girişimcilik aynı özelliklere sahip gözükse de her iki kavramda da geçerli olan ödül ve kazanım ve katlanmaları gereken kayıplar ölçek olarak farklılık göstermektedir.

İç girişimcilik hareket sahası olarak girişimciliğe göre daha dar bir hareket sahasına sahiptir çünkü var olan bir örgüt ve onun kuralları çerçevesinde hareket etmelidir (Donald ve Richard, 1998: 55-56).

Son dönem ekonomik yaşamdaki değişimler sebebiyle iç girişimcilik misalleri ciddi oranda artış göstermektedir. İşletmeler iç girişimcilik potansiyellerini artırmak amacıyla iç işleyiş sınırlarını genişletmek durumunda kalmışlardır.

İşletmelerde iç girişimcilik ortamı yaratılması bir takım şartların oluşup olgunlaşmasıyla alakalıdır. Bu şartlara bakıldığında öne çıkan unsurlar;

- İşletmelerin teknolojide öncü rolü oynamak arzusunda olmalarıdır. İşletmelerde Ar-Ge faaliyetleri yeni ve etkili ürünlerin piyasaya çıkmasında çok etkin rol oynar. İşletmeler bu önemli rol sebebiyle yeni teknolojileri yakından takip etmekle yükümlüdürler. Yenilikler sayesinde satış rakamlarının artması ve bu amaçla yapılan yatırımların geri dönüşü hızlı biçimde sağlanabilir (Kayış, 2010: 86).

- İç girişimcilik için verimli bir yapı kurmak isteyen işletmeler, yapılan hatalara toleransla yaklaşacak bir yapı kurmak durumundadırlar. Çalışanların yeni düşüncelerine, projeleri desteklenerek uygulama şansı verilmelidir (Başar ve Tosunoğlu, 2006: 123-134).

- İşletmelerde çalışanların yenilikçi fikirlerinin uygulamaya geçmesi için çalışanların önlerindeki engeller kaldırılmalıdır.

- İşletmelerin yenilikçi fikirlerin ortam bulması ve uygulamaya geçirilebilmesi için gerekli kaynaklar ulaşılabilir olmalıdır. İç girişimcilik teşebbüsü esnasında çalışanlar işletmeden bu fikirlerin uygulamaya geçebilmesi için kaynak talebinde bulunabilir. Burada harcanacak kaynak ile potansiyel getiri iyi hesaplanarak gereken kaynak tahsisi yapılmalıdır (Başar, 2004: 69).

\section{3. İç Girişimciliği Etkileyen Faktörler}

Serbest piyasa ekonomisinin hüküm sürdüğü ekonomik ortamlarda işletmelerin karmaşıklık ve hareketlilik içinde, çeşitli faaliyetleri aynı anda koordineli şekilde yönetmeleri gereklidir. $\mathrm{Bu}$ 
ortam dâhilinde gerçekleşen faaliyetlerin veya sürece etkide bulunan unsurların gelişimi çok çabuk, etkenlerin sayısı çok fazla ve karşılıklı etkileşimler yoğun biçimde olduğunda var olan kurumlar ve bağlı örgütler dairesinde belirsiz ve tehditlerin var olduğu bir çevre var olmaktadır.

İşletmeler bakımından çevre unsurlarının etkisi ile bireylerin beklentilerinin ve gereksinimlerinin çok daha karmaşık duruma gelerek, mevcut değer ve inanç sistemleri etkilemesi vasıtasıyla sürekli yeni firsat ve tehditler ortaya çıkmaktadır. Toplumsal hayatın içinde var olan ticari işletmelerin, faaliyetlerini çevresel faktörlerle yakın ilişki içinde yaptıkları düşünüldüğünde bu gelişimin etkisi olmadan faaliyetlerini sürdürmeleri mümkün değildir (Naktiyok ve Kök, 2006: 77).

İç girişimcilik süreci çevrede fark edilen potansiyel bir firsat ile başlar. Çevreden etkilenerek aynı zamanda içinde var oldukları çevreyi de etkileyebilen girişimciler ilgili faaliyetlerini, çevresel zorluklar ve belirsizliğe yanıt vererek çevre içinde kuvvetli stratejik pozisyon oluşturabilmek amaciyla yaparlar. Bu sebeple örgütlerin girişim dâhilinde çevresel şartlar oldukça etkili olmaktadır (Naktiyok ve Kök, 2006: 83).

\subsection{Bireysel Faktörler}

Bir organizasyonda çalışan bireylerin potansiyellerinin yansız olarak değerlendirilmesi kişisel farkların yenilikçi bir takım davranışlara olan etkilerini belirlemede ehemmiyetlidir. İç girişim potansiyeli amacıyla girişim potansiyeline sahip olan kişilerin belirlenme hedefi vardır. İç girişimcilik olgusunun etkin biçimde ortaya çıkması ve kuvvetlendirmesi amacıyla çalışanların sahip olması gereken bir takım yetenek, yetkinlik ile davranışların olması gerektiği ifade edilmiştir (Khan vd., 2011: 1-11).

Bunlar;

- Kayda değer yenilik yapabilmek amaciyla sosyal bilgilere sahip olmak,

- Girişimsel tavır ve anlayışa önem ve öncelik vermek,

- Girişimci yaklaşımda olmak,

- Öngörüleriyle diğerlerinin tespit edemediklerini belirlemek,

- İdareciler ve müşterilerle karşılıklı iletişim ve etkileşim içinde olmak,

- Teknik alanlarda verimli olmak,

- Örgüt içinde yenilik ve değişim süreçlerinde kendi başına yeterliliğe sahip olmak,

- Risk alma kapasitesi olmas1,

- Çatışmalar ve karşılaşılan belirsizliklere dair tolerans tanımak,

- Sonuç alabilmek amacıyla arzulu olmak,

- İçinde bulundukları örgüt kuvvetini ve var olan politikalarının farkında olmak (Yıldırım E,2014:411-428). 


\section{2. Örgütsel Faktörler}

İşletmelerde iç girişimciliğe etki eden örgütsel faktörler incelendiğinde örgütün yapısı, yönetimin verdiği destek, ücretlendirme politikaları, risk alma yönünde çalışanların ne derece teşvik edildiği ve bu noktada verilen kaynaklar dikkate alınmalıdır.

Girişimcilik bir örgütte etkin ise o işletmede yönetimin bu konudaki yaklaşımı da girişimcilik prensiplerine uygundur. Girişimci yönetim anlayışı vasıtasıyla örgütün en üst kademesinden daha aşağı kademelere kadar bu yaklaşımın yaygınlaştığı tespit edilmektedir. Örgüt içi idari kademeler çalışanların yenilik yapmaları amacıyla çalışanları her kademede destekleyip teşvik etmelerini kapsamaktadır. Girişim potansiyellerinin araştırılıp bulunması ve uygulamaya konulması ancak bu yönde yönetsel bir irade olması şartıyla başarılı olur. Yönetimlerin desteği işletmelerde potansiyel girişim ruhunun açığa çıkmasına yardımcı olur. Yönetimlerin anlatılan boyutta örgüt içinde iç girişimciliğe uygun bir ortam sağlanması için yadsınamaz bir rolü bulunmaktadır. İşletmelerin yönetsel anlamda iç girişimciliğe olan desteği içeride yapılan yeniliklerde bütün çalışanların emeği olduğuna dair inançla bütün çalışanları bu tip faaliyetlerin devamı konusunda cesaretlendirmektir (Akdoğan ve Cingöz, 2006: 25-27).

\subsection{Dış Çevresel Faktörler}

Örgütlerin iç girişimcilik faktörleri daha evvel bahsedilen bireysel ve örgütsel faktörlerin dışında dış çevre faktörleri de söz konusudur. Bu çevresel faktörler ülke politikaları, tüketicinin ve pazarın var olan talepleri, işletmenin kendi tedarikçilerinin vaziyeti vs. olabilmektedir. İç girişimcilik için bu belirleyici dış faktörler iç girişimcilik için belirsizlik faktörleri ve dinamik bir yapı olarak görülmektedir. İşletmeler genel olarak girişimci süreçlerin içine girmeye hevesli iseler aynı zamanda rekabetçi, hareketli bir pazarın içinde bulunmak durumundadırlar. Pazardaki teknolojik değişimler, beklentilerin çeşitlenip farklılaşması girişimci şirketleri ve şirketlerin bizatihi iç girişimcilik faaliyetlerini özendirebilir veya engelleyebilir (Naktiyok, 2004: 91).

\section{Araştırma}

Araştırmanın temel amacı, özel şirket çalışanlarının demografik özelliklerine göre iç girişimcilik olguları arasında fark olup olmadığının değerlendirilmesi olup, araştırmanın alt amacı ise özel sektör çalışanlarının iç girişimcilik olguları arasındaki ilişkinin varlığının araştırılmasıdır. Ayrıca iç girişimciliğin kurumun gelişmesindeki rolü saptanmaya çalışılmıştır.

\subsection{Araştırmanın Hipotezi}

H1: Cinsiyete göre; yönetim ve organizasyon teşviki, bireysel motivasyon, şeffaflık ve açıklık, yapıcı iş çevresi, yeniliğe teşvik, gelişme ve iç girişimcilik ortalamaları farklılık göstermektedir.

H2: Medeni duruma göre; yönetim ve organizasyon teşviki, bireysel motivasyon, şeffaflık ve açıklık, yapıcı iş çevresi, yeniliğe teşvik, gelişme ve iş girişimcilik ortalamaları farklılık göstermektedir.

H3: Girişimcilik eğitimi alıp almama durumuna göre; yönetim ve organizasyon teşviki, bireysel motivasyon, şeffaflık ve açıklık, yapıcı iş çevresi, yeniliğe teşvik, gelişme ve iş girişimcilik ortalamaları farklılık göstermektedir. 
H4: Yaşa göre; yönetim ve organizasyon teşviki, bireysel motivasyon, şeffaflık ve açıklık, yapıcı iş çevresi, yeniliğe teşvik, gelişme ve iş girişimcilik ortalamaları farklılık göstermektedir.

H5: Eğitim durumuna göre; yönetim ve organizasyon teşviki, bireysel motivasyon, şeffaflık ve açıklık, yapıcı iş çevresi, yeniliğe teşvik, gelişme ve iş girişimcilik ortalamaları farkl1l1k göstermektedir.

H6: Mesleki kıdeme göre; yönetim ve organizasyon teşviki, bireysel motivasyon, şeffaflık ve açıklık, yapıcı iş çevresi, yeniliğe teşvik, gelişme ve iş girişimcilik ortalamaları farkl111k göstermektedir.

H7: Gelire göre; yönetim ve organizasyon teşviki, bireysel motivasyon, şeffaflık ve açıklık, yapıcı iş çevresi, yeniliğe teşvik, gelişme ve iş girişimcilik ortalamaları farklılık göstermektedir.

H8: Personel sayısına göre; yönetim ve organizasyon teşviki, bireysel motivasyon, şeffaflık ve açıklık, yapıcı iş çevresi, yeniliğe teşvik, gelişme ve iş girişimcilik ortalamaları farkl111k göstermektedir.

H9: Yönetim ve organizasyon teşviki, bireysel motivasyon, şeffaflık ve açıklık, yapıcı iş çevresi, yeniliğe teşvik ve gelişme alt boyutları arasında pozitif anlamlı korelasyon vardır.

\subsection{Araştırmanın Yöntemi}

Araştırmanın örneklemini İstanbul Avrupa yakasında bulunan tekstil alanında faaliyet gösteren 15 özel kuruluş çalışanları oluşturmaktadır. Çalışmada kullanılabilir 201 adet anket cevapları analize tabi tutulmuştur.

Araştırmada demografik özellikleri belirlemek için, Mehmet Kızıloğlu ve Nurettin İbrahimoğlu tarafından kaleme alınan "İç Girişimcilik Olgusunun Yenilik Yapabilme Becerisine Etkisi: Gaziantep’te faaliyet gösteren Yenilikçi Örgütlerde Bir Uygulama” adlı makalesinden alınan bir "kişisel bilgi formu" kullanılmıştır. Diğer taraftan katılımcılara aynı makaleden alınan İç Girişimcilik Ölçeği uygulanmıştır.

Demografik bilgi formunda; katılımcıların cinsiyet, yaş, medeni durum, eğitim durumu, mesleki kıdem, işletmede çalışan kişi sayısı, aylık ortalama gelir ve girişimcilik eğitimi alma durumu bilgilerine yer verilmiştir.

İç Girişimcilik ölçeği, yönetim ve organizasyon teşviki, bireysel motivasyon, şeffaflık ve açıklık, bireysel yetkinlik, yapıcı iş çevresi, yeniliğe teşvik ve gelişme alt boyutlarından oluşan toplam 28 madde ile temsil edilmektedir.

Ankette yer alan demografik soruların ve iç girişimcilik ölçeğinin betimsel istatistikleri ve hipotez testleri SPSS (Statistical Packagefor the Social Sciences- Sosyal Bilimler için İstatistik Paketi) 21'de analiz edilmiştir. Betimsel istatistikler; frekans çizelgeleri, ortalama, standart sapma bilgilerinden oluşmaktadır. Analizlere başlamadan önce Güvenilirlik Analizi uygulanarak ölçeğin güvenilirliği test edilmiştir. Hipotez testlerinde normal dağılım varsayımı altında, grup sayısı iki olan kategorik değişkenlerin ölçek puanlarının karşılaştırılmasında bağımsız iki örnek T testi, grup sayısı ikiden fazla olan grupların karşılaştırılmasında tek yönlü anova kullanılmıştır. Alt ölçekler arasındaki korelasyon testi pearson korelasyon testi ile elde edilmiştir. Tüm analizlerde hata payı 0,05 olarak alınmıştır. 


\subsubsection{Araştırmadan Elde Edilen Bulgular}

$\mathrm{Bu}$ bölümde betimsel istatistikler ve analiz sonuçları yer almaktadır. Betimsel istatistikler kategorik değişkenler için frekans çizelgeleri ve sürekli değişkenler için de aritmetik ortalama ve standart sapma bilgilerinden oluşmaktadır.

\subsubsection{Demografik bulgular.}

Katılımcıların \%51,2'si (103) kadın ve \%48,8'i (98) erkeklerden oluşmaktadır.

Yaş grubu dağılımlarına göre; 18-24 yaş aralığında \%7,5 (15), 25-34 yaş aralığında \%66,6 (134), 35-44 yaş aralığında \%18,9 (38) ve 45 ve üzeri yaşta \%7 (14) oranında katılımcı yer almaktadir.

Eğitim düzeyi dağılımlarına göre; ön lisans mezunu katılımcıların oranı \%2,5 (5), lisans mezunu katılımcıların oranı $\% 74,1$ (149) ve lisansüstü mezunu olan katılımcıların oranı \%23,4 (47)'dir.

Medeni durum dağılımlarına göre katılımcıların \%48,3'ü (95) bekâr ve \%51,7'si (104) evlidir.

Katılımcıların mesleki kıdem dağılımlarına göre; 1 yıldan az iş tecrübesine sahip \%15,9 (32), 1 ile 4 yıl arası iş tecrübesine sahip \%57,2 (115), 5 ile 9 y1l arası iş tecrübesine sahip $\% 21,4$ (43) ve 10 yıl ve üzeri iş tecrübesine sahip \%5,5 (11) oranında katılımcı bulunmaktadır.

Aylık ortalama gelir dağılımlarına göre; 1500 TL ve altında aylık ortalama gelire sahip \%4,98 (10), 1501-2500 TL aralığında aylık ortalama gelire sahip \%25,37 (51), 2501-3500 TL aralığında aylık ortalama gelire sahip \%29,85 (60), 3501-4500 TL aralığında aylık ortalama gelire sahip \%19,9 (40) ve 4500 TL ve üzeri aylık ortalama gelire sahip \%19,9 (40) oranında katılımcı bulunmaktadır.

Katılımcılara çalıștıkları işletmedeki toplam personel sayısı da sorulmuştur. Alınan cevaplara göre; çalıştıkları işletmedeki toplam personel sayısı 10 ve altında olan \%5,5 (11), 11 30 arasında olan \%3 (6), 31-50 arasında olan \%4,5 (9), 51 ve üzeri olan \%87,1 (175) katılımc1 bulunmaktadır.

Katılımcıların \% 28,4'ü (57) girişimcilik eğitimi almış, \%71,6'sı (144) ise girişimcilik eğitimi almamıştır. 
Tablo 1: Araştırmaya Katılan Özel Sektör Çalışanlarının Demografik Özelliklerine İlişkin Bulgular

\begin{tabular}{|c|c|c|c|}
\hline \multicolumn{2}{|c|}{ Değişken } & \multirow{2}{*}{$\begin{array}{c}\text { Örneklem Sayıs1 } \\
103\end{array}$} & \multirow{2}{*}{$\frac{\text { Siklık (\%) }}{51,2}$} \\
\hline & Kadın & & \\
\hline & Erkek & 98 & 48,8 \\
\hline \multirow{4}{*}{ Yaş } & $18-24$ & 15 & 7,5 \\
\hline & $25-34$ & 134 & 66,6 \\
\hline & $35-44$ & 38 & 18,9 \\
\hline & 45 ve üzeri & 14 & 7 \\
\hline \multirow{3}{*}{ Eğitim Düzeyi } & Ön lisans & 5 & 2,5 \\
\hline & Lisans & 149 & 74,1 \\
\hline & Lisansüstü & 47 & 23,4 \\
\hline \multirow{2}{*}{ Medeni Durum } & Evli & 104 & 51,7 \\
\hline & Bekar & 95 & 48,3 \\
\hline \multirow{4}{*}{ Mesleki Kıdem } & 1 yildan az & 32 & 15,9 \\
\hline & $1-4$ y1l & 115 & 57,2 \\
\hline & $5-9$ y1l & 43 & 21,4 \\
\hline & 10 y1l ve üzeri & 11 & 5,5 \\
\hline \multirow{5}{*}{ Aylık Ortalama Gelir } & $1500 \mathrm{tl}$ & 10 & 4,98 \\
\hline & $1501-2500 \mathrm{tl}$ & 51 & 25,37 \\
\hline & $2501-3500 \mathrm{tl}$ & 60 & 29,85 \\
\hline & $3501-4500 \mathrm{tl}$ & 40 & 19,9 \\
\hline & 4500 ve üzeri & 40 & 19,9 \\
\hline \multirow{4}{*}{$\begin{array}{l}\text { İşletmede Çalışan Kişi } \\
\text { Sayısı }\end{array}$} & 10 ve daha az & 11 & 5,5 \\
\hline & $11-30$ aras1 & 6 & 3 \\
\hline & $31-50$ aras 1 & 9 & 4,5 \\
\hline & 51 ve üzeri & 175 & 87,1 \\
\hline \multirow{2}{*}{$\begin{array}{l}\text { Girişimcilik Eğitimi Alma } \\
\text { Durumu }\end{array}$} & Evet & 57 & 28,4 \\
\hline & Hayır & 144 & 71,6 \\
\hline
\end{tabular}




\subsubsection{2. İç Girişimcilik Ölçeğine İlişkin Bulgular}

Tablo 2: İç Girişimcilik Alt Ölçekleri Güvenilirlik Katsayıları

\begin{tabular}{|l|c|c|}
\hline \multicolumn{1}{|c|}{ İç Girişimcilik Alt Ölçekleri } & Madde Sayısı & Cronbach Alfa Katsayısı \\
\hline Yönetim ve Organizasyon Teşviki & 7 & 0,799 \\
\hline Bireysel Motivasyon & 5 & 0,836 \\
\hline Şeffaflık ve Açıklık & 5 & 0,826 \\
\hline Bireysel Yetkinlik & 2 & 0,540 \\
\hline Yapıcı İş Çevresi & 3 & 0,733 \\
\hline Yeniliğe Teşvik & 3 & 0,722 \\
\hline Gelişme & 3 & 0,720 \\
\hline
\end{tabular}

Tablo 2’ye göre İç Girişimcilik Ölçeği alt ölçeklerinin güvenilirlik katsayıları Yönetim ve Organizasyon Teşviki alt ölçeği için 0,799; Bireysel Motivasyon alt ölçeği için 0,836; Şeffaflık ve Açıklık alt ölçeği için 0,826; Bireysel Yetkinlik alt ölçeği için 0,540; Yapıcı İş Çevresi alt ölçeği için 0733; Yeniliğe Teşvik alt ölçeği için 0,722 ve Gelişme alt ölçeği için 0,720'dir. Bireysel Yetkinlik hariç tüm alt ölçeklerin "güvenilir" olduğu görülmektedir. Dolayısıyla bu alt ölçeklerle yapılan tüm analizlerin güvenilirliği de sağlanmış olmaktadır. Bireysel Yetkinlik alt ölçeği hem güvenilirlik katsayısı düşük olması hem de soru sayısının az olması nedeniyle analiz dışı bırakılmıştır. Analiz kapsamında Güvenilirlik Katsayısı dışında madde iç tutarlılık değerlerine de bakılmıştır. 
Tablo 3: İç Girişimcilik Ölçeği Alt Ölçekleri Madde İç Tutarlılık Değerleri

\begin{tabular}{|c|c|c|c|}
\hline Alt Ölçekler & Maddeler & $\begin{array}{c}\text { Düzeltilmiş Madde Toplam } \\
\text { İlişkisi }\end{array}$ & $\begin{array}{l}\text { Madde Silindiğinde } \\
\text { Cronbach Alfa Değeri }\end{array}$ \\
\hline \multirow{7}{*}{$\begin{array}{l}\text { Yönetim ve } \\
\text { Organizasyon } \\
\text { Teşviki }\end{array}$} & M1 & 0,456 & 0,787 \\
\hline & M2 & 0,505 & 0,778 \\
\hline & M3 & 0,608 & 0,759 \\
\hline & M4 & 0,615 & 0,757 \\
\hline & M5 & 0,488 & 0,781 \\
\hline & M6 & 0,642 & 0,755 \\
\hline & M7 & 0,428 & 0,795 \\
\hline \multirow{5}{*}{ Bireysel Motivasyon } & M8 & 0,700 & 0,784 \\
\hline & M9 & 0,694 & 0,786 \\
\hline & M10 & 0,648 & 0,799 \\
\hline & M11 & 0,664 & 0,795 \\
\hline & M12 & 0,486 & 0,844 \\
\hline \multirow{5}{*}{ Şeffaflık ve Açıklık } & M13 & 0,617 & 0,794 \\
\hline & M14 & 0,529 & 0,814 \\
\hline & M15 & 0,733 & 0,760 \\
\hline & M16 & 0,675 & 0,775 \\
\hline & M17 & 0,573 & 0,806 \\
\hline \multirow{3}{*}{ Yapıcı İş Çevresi } & M20 & 0,537 & 0,669 \\
\hline & M21 & 0,583 & 0,613 \\
\hline & M22 & 0,549 & 0,655 \\
\hline \multirow{3}{*}{ Yeniliğe Teşvik } & M23 & 0,517 & 0,667 \\
\hline & M24 & 0,578 & 0,591 \\
\hline & M25 & 0,541 & 0,641 \\
\hline \multirow{3}{*}{ Gelişme } & M26 & 0,503 & 0,687 \\
\hline & M27 & 0,682 & 0,459 \\
\hline & M28 & 0,456 & 0,726 \\
\hline
\end{tabular}

Tablo 3’te her bir alt ölçeğin hangi maddelerden oluştuğu, düzeltilmiş madde toplam ilişkisi ve madde silindiğinde Cronbach Alfa değerinin ne olacağı gösterilmektedir. 
Yönetim ve Organizasyon Teşviki alt ölçeğinin ilk 7 maddeden oluştuğu görülmektedir. Tablo 2'ye göre; 7 maddenin birlikte Cronbach Alfa değerinin 0,799 olduğu dikkate alındığında her bir maddenin analizden çıkarılmasının Cronbach Alfa değerini düşüreceği görülmektedir. $\mathrm{Bu}$ nedenle tüm maddeler analize dâhil edilmiştir.

Bireysel Motivasyon alt ölçeğinin 5 maddeden oluştuğu görülmektedir. Tablo 2'ye göre; 5 maddenin birlikte Cronbach Alfa değerinin 0,836 olduğu dikkate alındığında her bir maddenin analizden çıkarılmasının Cronbach Alfa değerini düşüreceği görülmektedir. $\mathrm{Bu}$ nedenle tüm maddeler analize dâhil edilmiştir.

Şeffaflık ve Açıklık alt ölçeğinin 5 maddeden oluştuğu görülmektedir. Tablo.2'ye göre; 5 maddenin birlikte Cronbach Alfa değerinin 0,826 olduğu dikkate alındığında her bir maddenin analizden çıkarılmasının Cronbach Alfa değerini düşüreceği görülmektedir. Bu nedenle tüm maddeler analize dâhil edilmiştir.

Yapıcı İş Çevresi alt ölçeği 3 maddeden oluşmaktadır. Tablo 2'ye göre; 3 maddenin birlikte Cronbach Alfa değeri 0,733'tür. Buna göre her bir maddenin analizden çıkarılması Cronbach Alfa değerini düşürecektir. Bu nedenle tüm maddeler analize dâhil edilmiştir.

Yeniliğe Teşvik alt ölçeğinin 3 maddeden oluştuğu görülmektedir. Tablo 2'ye göre; 3 maddenin birlikte Cronbach Alfa değerinin 0,722 olduğu dikkate alındığında her bir maddenin analizden çıkarılmasının Cronbach Alfa değerini düşüreceği görülmektedir. Bu nedenle tüm maddeler analize dâhil edilmiştir.

Gelişme alt ölçeği de 3 maddeden oluşmaktadır. Tablo 2'ye göre; 3 maddenin birlikte Cronbach Alfa değeri 0,720'dir. Buna göre Madde 28'in analizden çıkarılması Cronbach Alfa değerini arttıracaktır $(0,726)$. Ancak bu maddenin ölçeğin geneline yaptığı katkı ve Cronbach Alfa düzeyine yapacağı düşük etki göz önünde bulundurulduğunda analize dâhil edilmesine karar verilmiştir.

Tablo 4: İç Girişimcilik Ölçeği Alt Boyutlarına Ait Betimsel İstatistikler

\begin{tabular}{|l|c|c|c|c|}
\hline \multicolumn{1}{|c|}{ Alt Boyutlar } & Min. & Maks. & Aritmetik Ortalama & Standart Sapma \\
\hline $\begin{array}{l}\text { Yönetim ve } \\
\text { Organizasyon Teşviki }\end{array}$ & 9 & 35 & 24,05 & 5,26 \\
\hline Bireysel Motivasyon & 5 & 25 & 17,03 & 4,2 \\
\hline Şeffaflık ve Açıklık & 5 & 25 & 18,8 & 3,75 \\
\hline Yapıcı İş Çevresi & 3 & 15 & 10,06 & 2,58 \\
\hline Yeniliğe Teşvik & 3 & 15 & 10,58 & 2,35 \\
\hline Gelişme & 4 & 15 & 11,27 & 16,50 \\
\hline $\begin{array}{l}\text { İç Girişimcilik } \\
\text { Toplam Puan }\end{array}$ & 36 & 129 & 92,20 & \\
\hline
\end{tabular}

Tablo 4'e göre Yönetim ve Organizasyon Teşviki alt ölçeğinin aldığı en düşük değer 9 ve en yüksek değer 35; Bireysel Motivasyon ile Şeffaflık ve Açıklık alt ölçeğinin aldığı en düşük değer 5 ve en yüksek değer 25; Yapıcı İş Çevresi ve Yeniliğe Teşvik alt ölçeklerinin aldığı en düşük değer 3 ve en yüksek değer 15; Gelişme alt ölçeğinin aldığ1 en düşük değer 4 ve en yüksek değer 15; İç Girişimcilik toplam puanının aldığı en düşük değer 36 ve yüksek değer 
129'dur. Katılımcıların Yönetim ve Organizasyon Teşviki alt ölçeğinden aldıkları puanların ortalaması 24,05 ve standart sapması 5; Bireysel Motivasyon alt ölçeğinin ortalaması 17,03 ve standart sapması 4,20; Şeffaflık ve Açıklık alt ölçeğinin ortalaması 18,80 ve standart sapması 3,75; Yapıcı İş Çevresi alt ölçeğinin ortalamas 10,06 ve standart sapması 2,58; Yeniliğe Teşvik alt ölçeğinin ortalaması 10,58 ve standart sapması 2,59; Gelişme alt ölçeğinin alt ölçeğinin ortalaması 11,27 ve standart sapması 2,35 ve İç Girişimcilik toplamının ortalaması 92,20 ve standart sapmasi 16,50 'dir.

Tablo 5: Cinsiyete Göre İç Girişimcilik Alt Boyutlarının Değerlendirilmesi

\begin{tabular}{|c|c|c|c|c|c|c|}
\hline $\begin{array}{c}\text { İç Girişimcilik Alt } \\
\text { Boyutları }\end{array}$ & Cinsiyet & $\mathbf{N}$ & Ortalama & $\begin{array}{l}\text { Standart } \\
\text { Sapma }\end{array}$ & $\mathbf{t}$ & $\mathbf{p}$ \\
\hline $\begin{array}{l}\text { Yönetim ve } \\
\text { Organizasyon } \\
\text { Teşviki }\end{array}$ & $\begin{array}{l}\text { Kadın } \\
\text { Erkek }\end{array}$ & $\begin{array}{c}103 \\
98\end{array}$ & $\begin{array}{l}24,84 \\
23,23\end{array}$ & $\begin{array}{l}4,87 \\
5,54\end{array}$ & 2,188 & $0,030 *$ \\
\hline $\begin{array}{l}\text { Bireysel } \\
\text { Motivasyon }\end{array}$ & $\begin{array}{l}\text { Kadın } \\
\text { Erkek }\end{array}$ & $\begin{array}{c}103 \\
97\end{array}$ & $\begin{array}{l}17,54 \\
16,49\end{array}$ & $\begin{array}{l}3,82 \\
4,54\end{array}$ & 1,770 & 0,078 \\
\hline Şeffaflık ve Açıklık & $\begin{array}{l}\text { Kadın } \\
\text { Erkek }\end{array}$ & $\begin{array}{c}103 \\
98\end{array}$ & $\begin{array}{l}19,29 \\
18,29\end{array}$ & $\begin{array}{l}3,33 \\
4,11\end{array}$ & 1,889 & 0,060 \\
\hline Yapıcı İş Çevresi & $\begin{array}{l}\text { Kadın } \\
\text { Erkek }\end{array}$ & $\begin{array}{c}103 \\
98\end{array}$ & $\begin{array}{l}10,47 \\
9,63\end{array}$ & $\begin{array}{l}2,06 \\
2,98\end{array}$ & 2,335 & $0,021^{*}$ \\
\hline Yeniliğe Teşvik & $\begin{array}{l}\text { Kadın } \\
\text { Erkek }\end{array}$ & $\begin{array}{c}103 \\
98\end{array}$ & $\begin{array}{l}10,68 \\
10,47\end{array}$ & $\begin{array}{l}2,30 \\
2,86\end{array}$ & 0,573 & 0,568 \\
\hline Gelişme & $\begin{array}{l}\text { Kadın } \\
\text { Erkek }\end{array}$ & $\begin{array}{c}103 \\
96\end{array}$ & $\begin{array}{l}11,47 \\
11,06\end{array}$ & $\begin{array}{l}2,18 \\
2,52\end{array}$ & 1,239 & 0,217 \\
\hline $\begin{array}{l}\text { İç Girişimcilik } \\
\text { Toplam Puan }\end{array}$ & $\begin{array}{l}\text { Kadın } \\
\text { Erkek }\end{array}$ & $\begin{array}{c}103 \\
95\end{array}$ & $\begin{array}{l}94,32 \\
89,90\end{array}$ & $\begin{array}{l}14,40 \\
18,30\end{array}$ & 1,893 & 0,060 \\
\hline
\end{tabular}

\section{Bağımsız İki Örnek T Testi}

Cinsiyete göre İç Girişimcilik alt boyutları puanları arasında anlamlı farklılığın olup olmadığı Bağımsız İki Örnek T Testi ile analiz edilmiştir.

Tablo 5’e göre kadınların Yönetim ve Organizasyon Teşviki puanları, erkeklerden anlamlı düzeyde fazladır $(\mathrm{p}=0,03<0,05)$. Kadınların Yapıcı İş Çevresi puanları da, erkeklerden anlamlı düzeyde fazladır $(\mathrm{p}=0,021<0,05)$.

Bireysel Motivasyon, Şeffaflık ve Açıklık, Yeniliğe Teşvik, Gelişme ve İç Girişimcilik toplam puanlarına göre kadınların aldığı değerler erkeklerden daha yüksektir ancak bu fark anlamlı değildir ( $\mathrm{p}>0,05)$. 
Tablo 6: Medeni Duruma Göre İç Girişimcilik Alt Boyutlarının Değerlendirilmesi

\begin{tabular}{|c|c|c|c|c|c|c|}
\hline $\begin{array}{c}\text { İç } \\
\text { Girişimcilik } \\
\text { Alt Boyutları }\end{array}$ & $\begin{array}{l}\text { Medeni } \\
\text { Durum }\end{array}$ & $\mathbf{N}$ & Ortalama & $\begin{array}{c}\text { Standart } \\
\text { Sapma }\end{array}$ & $\mathbf{t}$ & $\mathbf{p}$ \\
\hline $\begin{array}{l}\text { Yönetim ve } \\
\text { Organizasyon } \\
\text { Teşviki }\end{array}$ & $\begin{array}{c}\text { Evli } \\
\text { Bekar }\end{array}$ & $\begin{array}{c}104 \\
95\end{array}$ & $\begin{array}{l}24,38 \\
23,84\end{array}$ & $\begin{array}{l}5,23 \\
5,25\end{array}$ & $\begin{array}{c}0,72 \\
9\end{array}$ & 0,467 \\
\hline $\begin{array}{l}\text { Bireysel } \\
\text { Motivasyon }\end{array}$ & $\begin{array}{c}\text { Evli } \\
\text { Bekar }\end{array}$ & $\begin{array}{c}103 \\
95\end{array}$ & $\begin{array}{l}17,87 \\
16,21\end{array}$ & $\begin{array}{l}3,95 \\
4,32\end{array}$ & $\begin{array}{c}2,82 \\
6\end{array}$ & $0,005 *$ \\
\hline $\begin{array}{l}\text { Şeffaflık ve } \\
\text { Açıklık }\end{array}$ & $\begin{array}{c}\text { Evli } \\
\text { Bekar }\end{array}$ & $\begin{array}{c}104 \\
95\end{array}$ & $\begin{array}{l}19,35 \\
18,23\end{array}$ & $\begin{array}{l}3,50 \\
3,95\end{array}$ & $\begin{array}{c}2,12 \\
6\end{array}$ & $0,035 *$ \\
\hline $\begin{array}{l}\text { Yapıcı İş } \\
\text { Çevresi }\end{array}$ & $\begin{array}{c}\text { Evli } \\
\text { Bekar }\end{array}$ & $\begin{array}{c}104 \\
95\end{array}$ & $\begin{array}{l}10,39 \\
9,75\end{array}$ & $\begin{array}{l}2,38 \\
2,73\end{array}$ & $\begin{array}{c}1,75 \\
1\end{array}$ & 0,082 \\
\hline $\begin{array}{l}\text { Yeniliğe } \\
\text { Teşvik }\end{array}$ & $\begin{array}{c}\text { Evli } \\
\text { Bekar }\end{array}$ & $\begin{array}{l}104 \\
95\end{array}$ & $\begin{array}{l}10,91 \\
10,26\end{array}$ & $\begin{array}{l}2,52 \\
2,64\end{array}$ & $\begin{array}{c}1,77 \\
4\end{array}$ & 0,078 \\
\hline Gelişme & $\begin{array}{c}\text { Evli } \\
\text { Bekar }\end{array}$ & $\begin{array}{c}104 \\
93\end{array}$ & $\begin{array}{l}11,72 \\
10,86\end{array}$ & $\begin{array}{l}2,11 \\
2,47\end{array}$ & $\begin{array}{c}2,62 \\
7\end{array}$ & $0,009 *$ \\
\hline $\begin{array}{l}\text { İç Girişimcilik } \\
\text { Toplam Puan }\end{array}$ & $\begin{array}{c}\text { Evli } \\
\text { Bekar }\end{array}$ & $\begin{array}{c}103 \\
93\end{array}$ & $\begin{array}{l}94,74 \\
89,81\end{array}$ & $\begin{array}{l}15,59 \\
17,06\end{array}$ & $\begin{array}{c}2,11 \\
3\end{array}$ & $0,036^{*}$ \\
\hline
\end{tabular}

\section{Bağımsız İki Örnek T Testi}

Katılımcıların medeni duruma göre İç Girişimcilik alt boyutları arasında anlamlı farklılığın olup olmadığı incelendiğinde; evli katılımcıların Bireysel Motivasyon, Şeffaflık ve Açıklık, Gelişme ve İç Girişimcilik toplam puanlarının ortalamalarının, bekâr katılımcılara göre anlamlı düzeyde yüksek olduğu görülmektedir $(\mathrm{p}<0,05)$.

Yönetim ve Organizasyon Teşviki, Yapıcı İş Çevresi ve Yeniliğe Teşvik alt boyutları açısından da evli katılımcıların ortalama puanları daha yüksektir ancak bu fark anlamlı değildir $(\mathrm{p}>0,05)$. 
Tablo 7: Girişimcilik Eğitimi Alma Durumuna Göre İç Girişimcilik Alt Boyutlarının Değerlendirilmesi

\begin{tabular}{|c|c|c|c|c|c|c|}
\hline $\begin{array}{c}\text { İç } \\
\text { Girişimcilik } \\
\text { Alt Boyutları }\end{array}$ & $\begin{array}{c}\text { İç } \\
\text { Girişimcilik } \\
\text { Eğitimi Alma }\end{array}$ & $\mathbf{N}$ & Ortalama & $\begin{array}{c}\text { Standart } \\
\text { Sapma }\end{array}$ & $\mathbf{t}$ & $\mathbf{p}$ \\
\hline $\begin{array}{l}\text { Yönetim ve } \\
\text { Organizasyon } \\
\text { Teşviki }\end{array}$ & $\begin{array}{l}\text { Evet } \\
\text { Hayır }\end{array}$ & $\begin{array}{c}57 \\
144\end{array}$ & $\begin{array}{l}24,50 \\
23,88\end{array}$ & $\begin{array}{l}5,40 \\
5,21\end{array}$ & 0,760 & 0,448 \\
\hline $\begin{array}{l}\text { Bireysel } \\
\text { Motivasyon }\end{array}$ & $\begin{array}{l}\text { Evet } \\
\text { Hayır }\end{array}$ & $\begin{array}{c}56 \\
144\end{array}$ & $\begin{array}{l}17,12 \\
17,00\end{array}$ & $\begin{array}{l}3,75 \\
4,38\end{array}$ & 0,188 & 0,851 \\
\hline $\begin{array}{l}\text { Şeffaflık ve } \\
\text { Açıklık }\end{array}$ & $\begin{array}{l}\text { Evet } \\
\text { Hayır }\end{array}$ & $\begin{array}{c}57 \\
144\end{array}$ & $\begin{array}{l}18,56 \\
18,90\end{array}$ & $\begin{array}{l}3,22 \\
3,95\end{array}$ & $\begin{array}{c}- \\
0,579\end{array}$ & 0,563 \\
\hline $\begin{array}{l}\text { Yapıcı İş } \\
\text { Çevresi }\end{array}$ & $\begin{array}{l}\text { Evet } \\
\text { Hayır }\end{array}$ & $\begin{array}{c}57 \\
144\end{array}$ & $\begin{array}{c}10,36 \\
9,94\end{array}$ & $\begin{array}{l}2,38 \\
2,66\end{array}$ & 1,048 & 0,296 \\
\hline $\begin{array}{l}\text { Yeniliğe } \\
\text { Teşvik }\end{array}$ & $\begin{array}{l}\text { Evet } \\
\text { Hayır }\end{array}$ & $\begin{array}{c}57 \\
144\end{array}$ & $\begin{array}{l}10,80 \\
10,50\end{array}$ & $\begin{array}{l}2,40 \\
2,66\end{array}$ & 0,756 & 0,450 \\
\hline Gelişme & $\begin{array}{l}\text { Evet } \\
\text { Hayır }\end{array}$ & $\begin{array}{c}57 \\
142\end{array}$ & $\begin{array}{l}11,43 \\
11,21\end{array}$ & $\begin{array}{l}2,18 \\
2,42\end{array}$ & 0,615 & 0,539 \\
\hline $\begin{array}{l}\text { İç Girişimcilik } \\
\text { Toplam Puan }\end{array}$ & $\begin{array}{l}\text { Evet } \\
\text { Hayır }\end{array}$ & $\begin{array}{c}56 \\
142\end{array}$ & $\begin{array}{l}92,98 \\
91,89\end{array}$ & $\begin{array}{l}15,31 \\
16,98\end{array}$ & 0,417 & 0,677 \\
\hline
\end{tabular}

\section{Bağımsız İki Örnek T Testi}

Girişimcilik eğitimi alma durumuna göre İç Girişimcilik alt boyutları arasında anlamlı farklılığın olup olmadığı incelendiğinde; Yönetim Organizasyon Teşviki, Bireysel Motivasyon, Yapıcı İş Çevresi, Yeniliğe Teşvik, Gelişme ve İç Girişimcilik toplam puanları açısından girişimcilik eğitimi alan katılımcıların ortalamaları, almayan katılımcılardan daha yüksektir ancak bu fark anlamlı değildir. Şeffaflık ve Açıklık açısından ise, girişimcilik eğitimi almayanların değerleri az bir farkla da olsa daha yüksektir $(\mathrm{p}>0,05)$. 
Tablo 8: Yaşa Göre İç Girişimcilik Alt Boyutlarının Değerlendirilmesi

\begin{tabular}{|c|c|c|c|c|c|c|}
\hline $\begin{array}{c}\text { İç } \\
\text { Girişimcilik } \\
\text { Alt Boyutları }\end{array}$ & Yaş & $\mathbf{N}$ & Ortalama & $\begin{array}{c}\text { Standart } \\
\text { Sapma }\end{array}$ & $\mathbf{F}$ & $\mathbf{p}$ \\
\hline $\begin{array}{l}\text { Yönetim ve } \\
\text { Organizasyon } \\
\text { Teşviki }\end{array}$ & $\begin{array}{c}\text { 18-24 } \\
25-34 \\
35-44 \\
45 \text { ve üzeri }\end{array}$ & $\begin{array}{c}15 \\
134 \\
38 \\
14\end{array}$ & $\begin{array}{l}26,60 \\
23,51 \\
24,07 \\
26,50\end{array}$ & $\begin{array}{l}4,89 \\
5,24 \\
5,35 \\
4,53\end{array}$ & 2,714 & $0,046^{*}$ \\
\hline $\begin{array}{l}\text { Bireysel } \\
\text { Motivasyon }\end{array}$ & $\begin{array}{c}\text { 18-24 } \\
25-34 \\
35-44 \\
45 \text { ve üzeri }\end{array}$ & $\begin{array}{c}15 \\
134 \\
37 \\
14\end{array}$ & $\begin{array}{l}18,40 \\
16,76 \\
17,29 \\
17,50\end{array}$ & $\begin{array}{l}4,56 \\
4,53 \\
3,11 \\
2,90\end{array}$ & 0,817 & 0,486 \\
\hline $\begin{array}{l}\text { Şeffaflık ve } \\
\text { Açıklık }\end{array}$ & $\begin{array}{c}\text { 18-24 } \\
25-34 \\
\text { 35-44 } \\
45 \text { ve üzeri }\end{array}$ & $\begin{array}{c}15 \\
134 \\
38 \\
14\end{array}$ & $\begin{array}{c}19,20 \\
18,68 \\
19 \\
19\end{array}$ & $\begin{array}{l}3,68 \\
3,83 \\
3,75 \\
3,39\end{array}$ & 0,144 & 0,933 \\
\hline $\begin{array}{l}\text { Yapıcı İş } \\
\text { Çevresi }\end{array}$ & $\begin{array}{c}\text { 18-24 } \\
25-34 \\
35-44 \\
45 \text { ve üzeri }\end{array}$ & $\begin{array}{c}15 \\
134 \\
38 \\
14\end{array}$ & $\begin{array}{c}10,66 \\
9,83 \\
10,39 \\
10,71\end{array}$ & $\begin{array}{l}3,17 \\
2,71 \\
2,13 \\
1,38\end{array}$ & 1,123 & 0,341 \\
\hline $\begin{array}{l}\text { Yeniliğe } \\
\text { Teşvik }\end{array}$ & $\begin{array}{c}\text { 18-24 } \\
25-34 \\
35-44 \\
45 \text { ve üzeri }\end{array}$ & $\begin{array}{c}15 \\
134 \\
38 \\
14\end{array}$ & $\begin{array}{l}11,06 \\
10,42 \\
10,84 \\
10,92\end{array}$ & $\begin{array}{l}2,21 \\
2,75 \\
2,41 \\
1,68\end{array}$ & 0,545 & 0,652 \\
\hline Gelişme & $\begin{array}{c}\text { 18-24 } \\
25-34 \\
35-44 \\
45 \text { ve üzeri }\end{array}$ & $\begin{array}{c}15 \\
132 \\
38 \\
14\end{array}$ & $\begin{array}{l}11,66 \\
11,13 \\
11,60 \\
11,28\end{array}$ & $\begin{array}{l}2,38 \\
2,39 \\
2,21 \\
2,39\end{array}$ & 0,536 & 0,658 \\
\hline $\begin{array}{l}\text { İç Girişimcilik } \\
\text { Toplam Puan }\end{array}$ & $\begin{array}{c}\text { 18-24 } \\
25-34 \\
35-44 \\
45 \text { ve üzeri }\end{array}$ & $\begin{array}{c}15 \\
132 \\
37 \\
14\end{array}$ & $\begin{array}{l}97,60 \\
90,83 \\
93,48 \\
95,92\end{array}$ & $\begin{array}{l}18,58 \\
17,12 \\
14,09 \\
13,35\end{array}$ & 1,153 & 0,329 \\
\hline
\end{tabular}

Katılımcıların yaşlarına göre İç Girişimcilik alt ölçekleri arasında anlamlı farklılığın olup olmadığı incelendiğinde; yaşa göre Yönetim ve Organizasyon Teşviki alt ölçeği açısından anlamlı farklılı̆̆ın olduğu görülmektedir. Farklılığın hangi grup ya da gruplardan kaynaklandığını görmek için yapılan Post Hoc testi sonucuna göre; 18-24 yaş grubu ve 45 yaş 
üzeri katılımcıların Yönetim ve Organizasyon Teşviki değerleri, 25-34 yaş grubundaki katılımcılardan anlamlı düzeyde yüksektir $(\mathrm{p}=0,046<0,05)$.

Bireysel Motivasyon, Şeffaflık ve Açıklık, Yeniliğe Teşvik, Gelişme alt ölçekleri ve İç Girişimcilik toplam puanları açısından 18-24 yaş grubundaki katılımcılarının aldıkları puanlar en yüksek değerlerken, 25-34 yaş grubu en düşük değerleri almaktadır. Yapıcı İş Çevresi alt ölçeğinde ise 25-34 yaş grubu en düşük, 45 ve üzeri yaş grubu ise en yüksek puanları almaktadır.

Tablo 9: Eğitim Düzeyine Göre İç Girişimcilik Alt Boyutlarının Değerlendirilmesi

\begin{tabular}{|c|c|c|c|c|c|c|}
\hline $\begin{array}{c}\text { İç } \\
\text { Girişimcilik } \\
\text { Alt Boyutları }\end{array}$ & Eğitim & $\mathbf{N}$ & Ortalama & $\begin{array}{l}\text { Standart } \\
\text { Sapma }\end{array}$ & $\mathbf{F}$ & $\mathbf{p}$ \\
\hline $\begin{array}{l}\text { Yönetim ve } \\
\text { Organizasyon } \\
\text { Teşviki }\end{array}$ & $\begin{array}{l}\text { Ön Lisans } \\
\text { Lisans } \\
\text { Lisansüstü }\end{array}$ & $\begin{array}{c}5 \\
149 \\
47\end{array}$ & $\begin{array}{l}23,80 \\
23,92 \\
24,51\end{array}$ & $\begin{array}{l}4,76 \\
5,08 \\
5,93\end{array}$ & 0,225 & 0,799 \\
\hline $\begin{array}{l}\text { Bireysel } \\
\text { Motivasyon }\end{array}$ & $\begin{array}{c}\text { Ön Lisans } \\
\text { Lisans } \\
\text { Lisansüstü }\end{array}$ & $\begin{array}{c}5 \\
148 \\
47\end{array}$ & $\begin{array}{l}18,40 \\
17,06 \\
16,97\end{array}$ & $\begin{array}{l}2,70 \\
4,17 \\
4,49\end{array}$ & 0,268 & 0,765 \\
\hline $\begin{array}{l}\text { Şeffaflık ve } \\
\text { Açıklık }\end{array}$ & $\begin{array}{c}\text { Ön Lisans } \\
\text { Lisans } \\
\text { Lisansüstü }\end{array}$ & $\begin{array}{c}5 \\
149 \\
47\end{array}$ & $\begin{array}{c}20 \\
18,59 \\
19,36\end{array}$ & $\begin{array}{l}2,73 \\
3,68 \\
4,06\end{array}$ & 1,011 & 0,366 \\
\hline $\begin{array}{l}\text { Yapıcı İş } \\
\text { Çevresi }\end{array}$ & $\begin{array}{c}\text { Ön Lisans } \\
\text { Lisans } \\
\text { Lisansüstü }\end{array}$ & $\begin{array}{c}5 \\
149 \\
47\end{array}$ & $\begin{array}{c}11,80 \\
9,91 \\
10,36\end{array}$ & $\begin{array}{l}1,78 \\
2,55 \\
2,69\end{array}$ & 1,704 & 0,185 \\
\hline $\begin{array}{l}\text { Yeniliğe } \\
\text { Teşvik }\end{array}$ & $\begin{array}{c}\text { Ön Lisans } \\
\text { Lisans } \\
\text { Lisansüstü }\end{array}$ & $\begin{array}{c}5 \\
149 \\
47\end{array}$ & $\begin{array}{l}10,80 \\
10,42 \\
11,06\end{array}$ & $\begin{array}{l}2,16 \\
2,68 \\
2,28\end{array}$ & 1,089 & 0,339 \\
\hline Gelişme & $\begin{array}{c}\text { Ön Lisans } \\
\text { Lisans } \\
\text { Lisansüstü }\end{array}$ & $\begin{array}{c}5 \\
147 \\
47\end{array}$ & $\begin{array}{l}10,40 \\
11,13 \\
11,80\end{array}$ & $\begin{array}{l}1,81 \\
2,33 \\
2,42\end{array}$ & 1,823 & 0,164 \\
\hline $\begin{array}{l}\text { İç Girişimcilik } \\
\text { Toplam Puan }\end{array}$ & $\begin{array}{c}\text { Ön Lisans } \\
\text { Lisans } \\
\text { Lisansüstü }\end{array}$ & $\begin{array}{c}5 \\
146 \\
47\end{array}$ & $\begin{array}{l}95,20 \\
91,49 \\
94,08\end{array}$ & $\begin{array}{l}12,31 \\
16,23 \\
17,76\end{array}$ & 0,521 & 0,595 \\
\hline
\end{tabular}

\section{Tek Yönlü ANOVA}

Tablo 9'dan da görüldüğü gibi İç Girişimcilik alt ölçekleri ve toplam puanları, eğitim düzeyine göre farklılık göstermemektedir. 
Tablo 10: Mesleki Kıdeme Göre İç Girişimcilik Alt Boyutlarının Değerlendirilmesi

\begin{tabular}{|c|c|c|c|c|c|c|}
\hline $\begin{array}{c}\text { İç } \\
\text { Girişimcilik } \\
\text { Alt Boyutları }\end{array}$ & $\begin{array}{l}\text { Mesleki } \\
\text { Kıdem }\end{array}$ & $\mathbf{N}$ & Ortalama & $\begin{array}{c}\text { Standart } \\
\text { Sapmaa }\end{array}$ & $\mathbf{F}$ & $\mathbf{p}$ \\
\hline $\begin{array}{l}\text { Yönetim ve } \\
\text { Organizasyon } \\
\text { Teşviki }\end{array}$ & $\begin{array}{c}1 \text { yıldan az } \\
1-4 \text { yıl } \\
5-9 \text { yıl } \\
10 \text { yıl ve üzeri }\end{array}$ & $\begin{array}{c}32 \\
115 \\
43 \\
11\end{array}$ & $\begin{array}{l}24,78 \\
23,13 \\
25,39 \\
26,45\end{array}$ & $\begin{array}{c}5 \\
5,20 \\
5,16 \\
5,46\end{array}$ & 3,178 & $0,025^{*}$ \\
\hline $\begin{array}{l}\text { Bireysel } \\
\text { Motivasyon }\end{array}$ & $\begin{array}{c}1 \text { yıldan az } \\
1-4 \text { yıl } \\
5-9 \text { yıl } \\
10 \text { yıl ve üzeri }\end{array}$ & $\begin{array}{c}32 \\
115 \\
43 \\
11\end{array}$ & $\begin{array}{l}18,03 \\
16,40 \\
17,60 \\
18,45\end{array}$ & $\begin{array}{l}3,78 \\
4,43 \\
3,87 \\
3,38\end{array}$ & 2,169 & 0,093 \\
\hline $\begin{array}{l}\text { Şeffaflık ve } \\
\text { Açıklık }\end{array}$ & $\begin{array}{c}1 \text { yıldan az } \\
1-4 \text { yıl } \\
5-9 \text { yıl } \\
10 \text { yıl ve üzeri }\end{array}$ & $\begin{array}{c}32 \\
115 \\
43 \\
11\end{array}$ & $\begin{array}{c}19,03 \\
18,45 \\
19,53 \\
19\end{array}$ & $\begin{array}{l}3,93 \\
3,60 \\
3,98 \\
3,94\end{array}$ & 0,926 & 0,429 \\
\hline $\begin{array}{l}\text { Yapıcı İşs } \\
\text { Çevresi }\end{array}$ & $\begin{array}{c}1 \text { yıldan az } \\
1-4 \text { yıl } \\
5-9 \text { yıl } \\
10 \text { yıl ve üzeri }\end{array}$ & $\begin{array}{c}32 \\
115 \\
43 \\
11\end{array}$ & $\begin{array}{c}10,37 \\
9,54 \\
10,97 \\
11\end{array}$ & $\begin{array}{l}2,62 \\
2,71 \\
2,05 \\
1,73\end{array}$ & 4,131 & $0,007 *$ \\
\hline $\begin{array}{l}\text { Yeniliğe } \\
\text { Teşvik }\end{array}$ & $\begin{array}{c}1 \text { yıldan az } \\
1-4 \text { yıl } \\
5-9 \text { yıl } \\
10 \text { yıl ve üzeri }\end{array}$ & $\begin{array}{c}32 \\
115 \\
43 \\
11\end{array}$ & $\begin{array}{c}10,90 \\
10,26 \\
11 \\
11,36\end{array}$ & $\begin{array}{l}2,42 \\
2,63 \\
2,69 \\
1,85\end{array}$ & 1,440 & 0,232 \\
\hline Gelişme & $\begin{array}{c}1 \text { yıldan az } \\
1-4 \text { yıl } \\
5-9 \text { yıl } \\
10 \text { yll ve üzeri }\end{array}$ & $\begin{array}{c}32 \\
115 \\
43 \\
11\end{array}$ & $\begin{array}{l}11,46 \\
11,08 \\
11,37 \\
12,27\end{array}$ & $\begin{array}{l}2,53 \\
2,32 \\
2,37 \\
1,95\end{array}$ & 0,991 & 0,398 \\
\hline $\begin{array}{l}\text { İç Girişimcilik } \\
\text { Toplam Puan }\end{array}$ & $\begin{array}{c}1 \text { yıldan az } \\
1-4 \text { yıl } \\
5-9 \text { yıl } \\
10 \text { yıl ve üzeri }\end{array}$ & $\begin{array}{c}32 \\
115 \\
43 \\
11\end{array}$ & $\begin{array}{l}94,59 \\
89,48 \\
95,88 \\
98,54\end{array}$ & $\begin{array}{l}17,31 \\
16,17 \\
16,23 \\
14,83\end{array}$ & 2,553 & 0,057 \\
\hline
\end{tabular}

\section{Tek Yönlü ANOVA}

Katılımcıların mesleki kıdemlerine göre Yönetim ve Organizasyon Teşviki puanları arasında anlamlı farklılık vardır ( $\mathrm{p}=0,025<0,05)$. Buna göre 10 yıl ve üzeri iş tecrübesine sahip katılımcıların Yönetim ve Organizasyon Teşviki ortalamaları en yüksektir. 10 yıl ve üzeri iş tecrübesine sahip katılımcıları, 5-9 yıl arasında iş tecrübesine sahip katılımcılar takip 
etmektedir. Post Hoc testi sonuçlarına göre; 10 yıl ve üzeri iş tecrübesine sahip olan katılımcıların Yönetim ve Organizasyon Teşviki ortalamaları, 1-4 yıl arasında iş tecrübesine sahip katılımcılardan anlamlı düzeyde fazladır.

Katılımcıların mesleki kıdemlerine göre Yapıcı İş Çevresi puanları arasında da anlamlı farklılık vardır $(\mathrm{p}=0,007<0,05)$. Buna göre 10 yıl ve üzeri iş tecrübesine sahip katılımcıların Yapıcı İş Çevresi ortalamaları en yüksektir. 10 yıl ve üzeri iş tecrübesine sahip katılımcıları, 59 yıl arasında iş tecrübesine sahip katılımcılar takip etmektedir. Post Hoc testi sonuçlarına göre; 10 yıl ve üzeri ve 5-9 yıl arası iş tecrübesine sahip olan katılımcıların Yapıcı İş Çevresi ortalamaları, 1-4 yıl arasında iş tecrübesine sahip katılımcılardan anlamlı düzeyde fazladır.

Bireysel Motivasyon, Şeffaflık ve Açıklık, Yeniliğe Teşvik, Gelişme ve İç Girişimcilik toplam puanlarının meslek kıdeme göre farklılık göstermediği görülmektedir.

Tablo 11: Aylık Ortalama Gelire Göre İç Girişimcilik Alt Boyutlarının Değerlendirilmesi

\begin{tabular}{|c|c|c|c|c|c|c|}
\hline $\begin{array}{c}\text { İç } \\
\text { Girişimcilik } \\
\text { Alt Boyutları }\end{array}$ & Gelir & $\mathbf{N}$ & Ortalama & $\begin{array}{l}\text { Standart } \\
\text { Sapma }\end{array}$ & $\mathbf{F}$ & $\mathbf{p}$ \\
\hline $\begin{array}{l}\text { Yönetim ve } \\
\text { Organizasyon } \\
\text { Teşviki }\end{array}$ & $\begin{array}{c}1500 \mathrm{TL} \text { ve altı } \\
\text { 1501-2500 TL } \\
2501-3500 \mathrm{TL} \\
\text { 3501-4500 TL } \\
4500 \mathrm{TL} \text { ve } \\
\text { üzeri }\end{array}$ & $\begin{array}{l}10 \\
51 \\
60 \\
40 \\
40\end{array}$ & $\begin{array}{l}24,50 \\
23,29 \\
22,71 \\
24,75 \\
26,25\end{array}$ & $\begin{array}{l}7,44 \\
5,23 \\
4,86 \\
5,06 \\
4,87\end{array}$ & 3,314 & $0,012^{*}$ \\
\hline $\begin{array}{l}\text { Bireysel } \\
\text { Motivasyon }\end{array}$ & $\begin{array}{c}1500 \mathrm{TL} \text { ve alt1 } \\
1501-2500 \mathrm{TL} \\
2501-3500 \mathrm{TL} \\
3501-4500 \mathrm{TL} \\
4500 \mathrm{TL} \text { ve } \\
\text { üzeri }\end{array}$ & $\begin{array}{l}10 \\
51 \\
60 \\
40 \\
40\end{array}$ & $\begin{array}{c}16,50 \\
16,25 \\
16,76 \\
17,60 \\
18\end{array}$ & $\begin{array}{l}6,72 \\
4,12 \\
4,03 \\
4,55 \\
3,32\end{array}$ & 1,252 & 0,290 \\
\hline $\begin{array}{l}\text { Şeffaflık ve } \\
\text { Açıklık }\end{array}$ & $\begin{array}{c}1500 \mathrm{TL} \text { ve alt1 } \\
\text { 1501-2500 TL } \\
2501-3500 \mathrm{TL} \\
3501-4500 \mathrm{TL} \\
4500 \mathrm{TL} \text { ve } \\
\text { üzeri }\end{array}$ & $\begin{array}{l}10 \\
51 \\
60 \\
40 \\
40\end{array}$ & $\begin{array}{l}17,10 \\
18,13 \\
19,35 \\
19,37 \\
18,70\end{array}$ & $\begin{array}{l}6,10 \\
3,76 \\
2,91 \\
3,62 \\
4,19\end{array}$ & 1,484 & 0,208 \\
\hline $\begin{array}{l}\text { Yapıcı İş } \\
\text { Çevresi }\end{array}$ & $\begin{array}{l}1500 \mathrm{TL} \text { ve alt1 } \\
1501-2500 \mathrm{TL} \\
2501-3500 \mathrm{TL} \\
3501-4500 \mathrm{TL}\end{array}$ & $\begin{array}{l}10 \\
51 \\
60 \\
40 \\
40\end{array}$ & $\begin{array}{c}9 \\
9,98 \\
9,60 \\
10,35 \\
10,85\end{array}$ & $\begin{array}{l}3,55 \\
2,02 \\
2,99 \\
2,71 \\
1,96\end{array}$ & 2,004 & 0,095 \\
\hline
\end{tabular}




\begin{tabular}{|c|c|c|c|c|c|c|}
\hline & $\begin{array}{c}4500 \text { TL ve } \\
\text { üzeri }\end{array}$ & & & & & \\
\hline \multirow{5}{*}{$\begin{array}{l}\text { Yeniliğe } \\
\text { Teşvik }\end{array}$} & $1500 \mathrm{TL}$ ve alt 1 & 10 & 10,70 & 2,90 & \multirow[t]{5}{*}{2,220} & \multirow[t]{5}{*}{0,068} \\
\hline & 1501-2500 TL & 51 & 9,84 & 2,59 & & \\
\hline & 2501-3500 TL & 60 & 10,41 & 2,78 & & \\
\hline & 3501-4500 TL & 40 & 11,25 & 2,59 & & \\
\hline & $\begin{array}{c}4500 \text { TL ve } \\
\text { üzeri }\end{array}$ & 40 & 11,10 & 1,97 & & \\
\hline \multirow{5}{*}{ Gelişme } & $1500 \mathrm{TL}$ ve alt 1 & 10 & 10,88 & 2,84 & \multirow[t]{5}{*}{1,989} & \multirow[t]{5}{*}{0,098} \\
\hline & $1501-2500 \mathrm{TL}$ & 51 & 10,80 & 2,47 & & \\
\hline & 2501-3500 TL & 60 & 11,11 & 2,21 & & \\
\hline & 3501-4500 TL & 40 & 11,35 & 2,42 & & \\
\hline & $\begin{array}{c}4500 \text { TL ve } \\
\text { üzeri }\end{array}$ & 40 & 12,12 & 2,09 & & \\
\hline \multirow{5}{*}{$\begin{array}{l}\text { İç Girişimcilik } \\
\text { Toplam Puan }\end{array}$} & $1500 \mathrm{TL}$ ve alt 1 & 10 & 94,55 & 19,23 & \multirow[t]{5}{*}{2,061} & \multirow[t]{5}{*}{0,088} \\
\hline & 1501-2500 TL & 51 & 88,44 & 17,10 & & \\
\hline & 2501-3500 TL & 60 & 90,08 & 15,43 & & \\
\hline & 3501-4500 TL & 40 & 94,67 & 17,04 & & \\
\hline & $\begin{array}{c}4500 \text { TL ve } \\
\text { üzeri }\end{array}$ & 40 & 97,02 & 15,17 & & \\
\hline
\end{tabular}

\section{Tek Yönlü ANOVA}

Katılımcıların aylık ortalama gelirlerine göre Yönetim ve Organizasyon Teşviki puanları arasında anlamlı farklılık vardır $(p=0,012<0,05)$. Buna göre $4500 \mathrm{TL}$ ve üzeri aylık gelire sahip katılımcıların Yönetim ve Organizasyon Teşviki ortalamaları en yüksektir. En düşük Yönetim ve Organizasyon Teşviki ortalamalarına sahip grup ise 2501-3500 TL aylık gelire sahip katılımcılardır. Post Hoc testi sonuçlarına göre de; 4500 TL ve üzeri aylık gelire sahip katılımcıların Yönetim ve Organizasyon Teşviki ortalamaları, 2501-3500 TL gelire sahip katılımcılardan anlamlı düzeyde yüksektir.

Diğer tüm alt ölçekler ve İç Girişimcilik toplam puanları dikkate alındığında, katılımcıların aylık ortalama gelirlerine göre anlamlı fark tespit edilememiştir. 
Tablo 12: İşletmede Çalışan Kişi Sayısına Göre İç Girişimcilik Alt Boyutlarının Değerlendirilmesi

\begin{tabular}{|c|c|c|c|c|c|c|}
\hline $\begin{array}{c}\text { İç } \\
\text { Girişimcilik } \\
\text { Alt Boyutları }\end{array}$ & $\begin{array}{l}\text { Personel } \\
\text { Sayısı }\end{array}$ & $\mathbf{N}$ & Ortalama & $\begin{array}{l}\text { Standart } \\
\text { Sapma }\end{array}$ & F & $\mathbf{p}$ \\
\hline $\begin{array}{l}\text { Yönetim ve } \\
\text { Organizasyon } \\
\text { Teşviki }\end{array}$ & $\begin{array}{c}10 \text { ve alt1 } \\
11-30 \\
31-50 \\
51 \text { ve üzeri }\end{array}$ & $\begin{array}{c}11 \\
6 \\
9 \\
175\end{array}$ & $\begin{array}{l}26,09 \\
20,50 \\
26,88 \\
23,82\end{array}$ & $\begin{array}{l}6,37 \\
0,70 \\
4,04 \\
5,23\end{array}$ & 1,853 & 0,139 \\
\hline $\begin{array}{l}\text { Bireysel } \\
\text { Motivasyon }\end{array}$ & $\begin{array}{c}10 \text { ve alt1 } \\
11-30 \\
31-50 \\
51 \text { ve üzeri }\end{array}$ & $\begin{array}{c}11 \\
6 \\
9 \\
175\end{array}$ & $\begin{array}{c}18,09 \\
17 \\
18,33 \\
16,90\end{array}$ & $\begin{array}{l}3,47 \\
0,00 \\
3,27 \\
4,29\end{array}$ & 0,574 & 0,633 \\
\hline $\begin{array}{l}\text { Şeffaflık ve } \\
\text { Açıklık }\end{array}$ & $\begin{array}{c}10 \text { ve altı } \\
11-30 \\
31-50 \\
51 \text { ve üzeri }\end{array}$ & $\begin{array}{c}11 \\
6 \\
9 \\
175\end{array}$ & $\begin{array}{l}18,54 \\
15,50 \\
18,77 \\
18,87\end{array}$ & $\begin{array}{l}3,29 \\
2,12 \\
2,53 \\
3,86\end{array}$ & 1,544 & 0,653 \\
\hline $\begin{array}{l}\text { Yapicı İş } \\
\text { Çevresi }\end{array}$ & $\begin{array}{c}10 \text { ve alt1 } \\
11-30 \\
31-50 \\
51 \text { ve üzeri }\end{array}$ & $\begin{array}{c}11 \\
6 \\
9 \\
175\end{array}$ & $\begin{array}{c}11,27 \\
10,50 \\
11 \\
9,90\end{array}$ & $\begin{array}{l}2,57 \\
2,12 \\
1,58 \\
2,60\end{array}$ & 1,438 & 0,233 \\
\hline $\begin{array}{l}\text { Yeniliğe } \\
\text { Teşvik }\end{array}$ & $\begin{array}{c}10 \text { ve alt1 } \\
11-30 \\
31-50 \\
51 \text { ve üzeri }\end{array}$ & $\begin{array}{c}11 \\
6 \\
9 \\
175\end{array}$ & $\begin{array}{c}10,90 \\
9 \\
11,11 \\
10,55\end{array}$ & $\begin{array}{l}2,50 \\
1,41 \\
1,76 \\
2,65\end{array}$ & 0,431 & 0,731 \\
\hline Gelişme & $\begin{array}{c}10 \text { ve alt1 } \\
11-30 \\
31-50 \\
51 \text { ve üzeri }\end{array}$ & $\begin{array}{c}11 \\
6 \\
9 \\
175\end{array}$ & $\begin{array}{c}11,45 \\
10 \\
11,22 \\
11,25\end{array}$ & $\begin{array}{c}2,80 \\
0 \\
2,04 \\
2,34\end{array}$ & 0,121 & 0,948 \\
\hline $\begin{array}{l}\text { İç Girişimcilik } \\
\text { Toplam Puan }\end{array}$ & $\begin{array}{c}10 \text { ve alt1 } \\
11-30 \\
31-50 \\
51 \text { ve üzeri }\end{array}$ & $\begin{array}{c}11 \\
6 \\
9 \\
175\end{array}$ & $\begin{array}{c}96,36 \\
84 \\
97,33 \\
91,68\end{array}$ & $\begin{array}{c}19,48 \\
0 \\
10,36 \\
16,53\end{array}$ & 0,663 & 0,576 \\
\hline
\end{tabular}

\section{Tek Yönlü ANOVA}

12 no’lu tablodan da görüldüğü gibi İç Girişimcilik alt ölçekleri ve toplam puanları, işletmede çalışan kişi sayısına göre farklılık göstermemektedir. 
Tablo 13: İç Girişimcilik Alt Ölçekleri Arasındaki İlişkinin Değerlendirilmesi

\begin{tabular}{|c|c|c|c|c|c|c|c|}
\hline & & $\begin{array}{c}\text { Yönetim ve } \\
\text { Organizasyon } \\
\text { Teşviki }\end{array}$ & $\begin{array}{c}\text { Bireysel } \\
\text { Motivasyon }\end{array}$ & $\begin{array}{l}\text { Şeffaflık ve } \\
\text { Açıklık }\end{array}$ & $\begin{array}{l}\text { Yapıci İş } \\
\text { Çevresi }\end{array}$ & $\begin{array}{c}\text { Yeniliğe } \\
\text { Teşvik }\end{array}$ & Gelişme \\
\hline \multirow{2}{*}{$\begin{array}{l}\text { Yönetim ve } \\
\text { Organizasyon } \\
\text { Teşviki }\end{array}$} & r & 1 & 0,697 & 0,631 & 0,602 & 0,571 & 0,529 \\
\hline & $\mathrm{p}$ & & $0,000^{*}$ & $0,000^{*}$ & $0,000^{*}$ & $0,000 *$ & $0,000^{*}$ \\
\hline \multirow{2}{*}{$\begin{array}{l}\text { Bireysel } \\
\text { Motivasyon }\end{array}$} & r & & 1 & 0,597 & 0,668 & 0,541 & 0,562 \\
\hline & $\mathrm{p}$ & & & $0,000^{*}$ & $0,000^{*}$ & $0,000^{*}$ & $0,000^{*}$ \\
\hline \multirow{2}{*}{$\begin{array}{l}\text { Şeffaflık ve } \\
\text { Açıklık }\end{array}$} & r & & & 1 & 0,590 & 0,557 & 0,495 \\
\hline & $\mathrm{p}$ & & & & $0,000 *$ & $0,000^{*}$ & $0,000 *$ \\
\hline \multirow{2}{*}{ Yapıcı İş Çevresi } & $\mathrm{r}$ & & & & 1 & 0,549 & 0,486 \\
\hline & $\mathrm{p}$ & & & & & $0,000 *$ & $0,000^{*}$ \\
\hline \multirow{2}{*}{ Yeniliğe Teşvik } & $\mathrm{r}$ & & & & & 1 & 0,509 \\
\hline & $\mathrm{p}$ & & & & & & $0,000^{*}$ \\
\hline \multirow{2}{*}{ Gelişme } & $\mathrm{r}$ & & & & & & 1 \\
\hline & $\mathrm{p}$ & & & & & & \\
\hline
\end{tabular}

Tablo 13’te İç Girişimcilik alt ölçekleri arasındaki korelasyon katsayıları görülmektedir. Buna göre Yönetim ve Organizasyon Teşviki ile Bireysel Motivasyon arasında pozitif yönlü güçlü bir ilişki vardır ve bu ilişki anlamlıdır $(r=0,697$ ve $p=0,000<0,05)$. Benzer şekilde Yönetim ve Organizasyon Teşviki ile Bireysel Motivasyon, Şeffaflık ve Açıklık, Yapıcı İş Çevresi, Yeniliğe Teşvik ve Gelişme alt ölçekleri arasında anlamlı ve pozitif bir ilişki mevcuttur.

Bireysel Motivasyon alt ölçeği ile en yükssek ilişkiye sahip değişken, Yapıcı İş Çevresi alt ölçeğidir. Aralarında iyi düzeyde ve pozitif bir ilişki söz konusudur. Aynı şekilde diğer alt ölçeklerle de pozitif yönlü, iyi düzeyde ve güçlü ilişki mevcuttur.

\section{Sonuç ve Öneriler}

Yapılan analizler sonrası elde edilen sonuçlara göre kadınların yönetim ve organizasyon teşviki ve yapıcı iş çevresi puanları erkeklerden anlamlı düzeyde fazladır.

Evli katılımcıların bireysel motivasyon, şeffaflık ve açıklık, gelişme ve iç girişimcilik toplam puanlarının ortalamalarının bekar katılımcılara göre anlamlı düzeyde yüksek olduğu görülmektedir.

18-24 yaş grubundaki katılımcılar bireysel motivasyon, şeffaflık ve açıklık, yeniliğe teşvik ve gelişme alt ölçekleri ve iç girişimcilik toplam puanları açısından en yüksek puanları almışlardır. Yapıcı iş çevresi alt ölçeğinde ise 45 yaş ve üzeri grup en yüksek puanı almıştır. 
10 y1l ve üzeri iş tecrübesine sahip katılımcıların yönetim ve organizasyon teşviki ortalamaları en yüksektir. Bunu 5-9 y1l iş tecrübesine sahip katılımcılar takip etmektedir. Ayrıca 10 yıl ve üzeri iş tecrübesine sahip katılımcıların yapıcı iş çevresi ortalamaları da en yüksektir.

4500 tl ve üzeri aylık gelire sahip olan katılımcıların yönetim ve organizasyon teşviki ortalamas1 en yüksektir.

Yönetim ve organizasyon teşviki ile bireysel motivasyon, şeffaflık ve açıklık, yapıcı iş çevresi, yeniliğe teşvik ve gelişme alt ölçekleri arasında anlamlı ve pozitif bir ilişki mevcuttur.

Yapılan analizlerden de anlaşılacağı üzere katılımcıların cinsiyet, medeni durum, yaş, iş tecrübesi, aylık gelir gibi demografik özellikleri ile iç girişimcilik alt boyutları arasında anlamlı ve pozitif bir ilişki mevcuttur. Bu sonuç hipotezi destekler biçimdedir.

$\mathrm{Bu}$ durumda çalışanlarda iç girişimcilik olgusunu desteklemek ve geliştirmek için demografik özellikler dikkate alınmalı, iş çevresi, çalışanları motive edici şekilde düzenlenmelidir.

Diğer yandan eğitim düzeyi ve işletmede çalışan kişi sayısı değişkenleri dikkate alındığında ise iç girişimcilik alt ölçeklerinin ve iç girişimcilik toplam puanlarının bu değişkenlere bağlı olarak farklılık göstermediği saptanmıştır.

Ayrıca bu çalışmanın sonucunda, iç girişimciliğe dair önceki çalışmalarla da benzer olarak iç girişimciliğin kuruma olan bağlılığı arttırdığı, kurumun gelişmesinde katkıda bulunduğu saptanmıştır. Farklı olarak bu çalışma kapsamında kurum bünyesindeki çalışanların kurumsal bağlılıklarının da iç girişimciliği arttırdığı ve teşvik ettiği saptanmıştır. Yine önceki çalışmalardan farklı olarak kurum kapsamında gerçekleştirilen demografik analizlere göre yeni jenerasyonlara ağırlık veren kurumlarda, inovatif düşünme tarzına daha yatkın olunduğu ve iç girişimciliğe daha pozitif bir perspektiften bakıldığ 1 saptanmıştır.

İşletmelerde iç girişimcilik olgusu ile ilgili olarak yapılacak yeni çalışmalara yol göstermek ve çalışmayı daha ileriye taşımak adına çalışmanın evren ve örneklemi arttırılabilir. $\mathrm{Bu}$ çalışma sadece İstanbul Avrupa yakasında tekstil alanında faaliyet gösteren firmalara yönelik olarak yapılmıştır. Fakat iç girişimcilik olgusu sadece tekstil firmalarında değil, farklı sektörlerde faaliyet gösteren birçok firmanın ortak konusu olduğundan, araştırma birçok sektörde faaliyet gösteren kurumsal firmalara yönelik olarak yapılabilir. Bu durumda ölçeğin uygulanacağı kişi sayısı da artacağından, çıkan sonuçlar daha net sonuçlar olabilir.

Gelecek çalışmalara yol gösterebilmek adına önerilecek bir diğer çalışma ise, sadece tekstil alanında faaliyet gösteren fakat Türkiye genelinde tekstil alanında gelişmiş, Bursa, Denizli gibi şehirlerde yerleşik firmalara yönelik olarak da böyle bir çalışma yapılabilir ve böylece iç girişimcilik olgusunun kurumsal tekstil firmalarındaki yeri hakkında daha net bilgilere ulaşılabilir. Ayrıca bu çalışma farklı sektörlerde de yapılarak sektörler arası karşılaştırmaya da olanak sağlanabilir. 


\section{Kaynakça}

Akdoğan, A. \& Cingöz, A. (2006). "İç Girişimciliğe Verilen Önem Düzeyi Ve İç Girişimciliği Etkileyen Örgütsel Faktörlerin Belirlenmesine Yönelik Kayseri İlinde Bir Araştırma”, Uluslararası Girişimcilik Kongresi Bişkek7

Arıkan, S. (2002). Girişimcilik: Temel Kavramlar ve Bazı Güncel Konular, Siyasal Kitabevi, Ankara.

Başar, M. (2004). İç Girişimcilik, Anadolu Üniversitesi Yayınları, Eskişehir.

Başar, M. \& Tosunoğlu, B. T. (2006). "Değer yaratımında iç girişimciliğin değiş̧en boyutu: Bilgi girişimcilerinin rolü”. Girişimcilik ve Kalkınma Dergisi

Durak, İ. (2011). "Girişimciliği Etkileyen Çevresel Faktörlerle İlgili Girişimcilerin Tutumları: Bir Alan Araştırması”, Yönetim Bilimleri Dergisi,

Durğun, S. (2006). “Örgüt Kültürü ve Örgütsel İletişim”, Yüzüncü Yıl Üniversitesi Eğitim Fakültesi Dergisi

Kayış, A. (2010). "Girişimcilik ve İç Girişimciliğin Önündeki Engeller: Yazılım Sektöründe Bir Uygulama”, Yayınlanmamış Yüksek Lisans Tezi, Gebze Yüksek Teknoloji Enstitüsü Sosyal Bilimler Enstitüsü, Gebze.

Khan, B. A., Budhwani, Z. R. \& Shaikh, A. (2011). "Practicing the Entrepreneurship: a Case of Service-Sector Firms in Pakistan”. Journal of Management and Social Sciences

Kök, S. B. (2007). Küçük ve Orta Ölçekli İşletmeler ve Kadın Girişimciliği, Gazi Kitabevi, Ankara.

Kuratko F. Donald, Hodgetts Richard, M. (2001). Entrepreneurship, Fourth Edition, The Dreyden Press, Orlando.

Naktiyok, A. (2004). İç girişimcilik, Beta Basım Yayım Dağıtım, İstanbul.

Naktiyok, A. \& Kök, B. S. (2006). “Çevresel faktörlerin iç girişimcilik üzerine etkileri”. Afyon Kocatepe Üniversitesi Iktisadi ve İdari Bilimler Fakültesi Dergisi

Öktem, M. K., Leblebici, D. N., Arslan, M., Kılıç, M. ve Aydın, M.D. (2003). "Girişimci Örgütsel Kültür ve Çalışanların İç Girişimcilik Düzeyi: Uygulamalı Bir Çalışma”, Hacettepe Üniversitesi İktisadi ve İdari Bilimler Fakültesi Dergisi

Vural, U. (2016). “Türkiye’de Kadın ve Erkek Girişimcilerin Başarılarının Sosyal ve Ekonomik Bakımdan Karşılaştırılması”, Yayınlanmamış Yüksek Lisans Tezi, Aydın Üniversitesi, İstanbul. 


\section{EXTENDED ABSTRACT}

\section{A Field Study on Determining the Differences Between Internal Entrepreneurship phenomenon by Demographic Characteristics of Private Sector Employees}

Internal entrepreneurship is the act of initiative in a narrower field of action. Contrary to independent action here, there is an affiliated organization, and this organization must be acted upon within the framework of its rules.

In order to determine the entrepreneurship nature of the enterprises, mid-level managerial entrepreneurship questionnaire was applied to randomly selected 201 employees from 15 textile firms operating in European side of Istanbul in 2016-2017.

The data obtained from the questionnaires was analyzed and as a result of the analysis findings were stated in the research section of the study.

A personal information form and internal entrepreneurship scale were used to determine the demographic characteristics of the survey as a data collection tool.

The personal information form applied to the middle level managers included information on gender, age, marital status, educational status, occupational seniority, number of persons working in the enterprise, monthly average income and entrepreneurship education status.

The sub-scales of the internal entrepreneurship survey consist of individual motivation, transparency and openness, individual competence, constructive business environment, innovation incentives and development scales. Individual competence, one of these subscales, was not included in the analysis since the reliability coefficient was low and the number of questions was low.

Findings obtained from the research were classified as findings related to personal information and findings related to internal entrepreneurship scale.

Findings related to personal information are as follows: 51.2\% men and 42.8\% of total 201 participants are women. The number of female participants is more than male participants.

$7,5 \%$ of participants were in the $18-24$ age group, $66,7 \%$ were in the $25-34$ age group, $18,9 \%$ were in the $35-44$ age group, $7 \%$ were in the 45 and above age group. The vast majority of participants comprise the 25-34 age group.

$2.5 \%$ of the participants had associate degree, $74.1 \%$ had undergraduate degree and $23.4 \%$ had postgraduate degree. The majority of participants have undergraduate degree

When we look at the marital status of participants, $47.3 \%$ are single and $51.7 \%$ are married. The number of married participants is higher than the number of single participants.

$15.9 \%$ of the participants had less than 1 year of job experience, $57.2 \%$ of them had $1-4$ years, $21.4 \%$ of them had 5-9 years, 5.5\% of them had 10 years of job experience. The number of participants who are between 1-4 years of job experience is considerably higher than others.

According to monthly average income distribution; $5 \%$ of the participants had a monthly average income of 1500 TL or less, $25.4 \%$ had a monthly average income of $1501-2500$ TL, $29.9 \%$ had a monthly average income of 2501-3500 TL, $19.9 \%$ had a monthly average income of 3501-4500 TL and 19.9\% had a monthly average income of $4500 \mathrm{TL}$ and above. The average monthly income is between 2501 and 3500 TL.

Findings of internal entrepreneurship scale are as follows.

According to gender, the scores of female participants in management and organizational incentives and constructive business environment subscales are significantly higher than male participants' scores. 
When the marital status is taken into account, married participants' scores in individual motivation, transparency and openness, development and internal entrepreneurship scores were found to be significantly higher than the scores of single participants.

The incentive values for management and organization of the participants in the 18-24 age group and 45 and above age group are significantly higher than the 25-34 age group.

When we look at the occupational seniority of participants, it is seen that the group with the highest average management and organizational incentive and constructive business environment has been working for 10 years or more.

When the monthly average income is taken into consideration, it is reached that the participants with monthly income of $4500 \mathrm{TL}$ and above have the highest average management and organization incentive, while the participants with the monthly income between 2501-3500 TL have the lowest average.

When the education level and the number of people working in the business are taken into account, it is determined that the total scores of internal entrepreneurship sub-scales and internal entrepreneurship do not differ depending on these variables.

This research was carried out only for firms operating in the field of textiles European side of Istanbul. Future studies can remove these constraints and achieve more reliable results by applying the internal entrepreneurship scale to other firms operating in sectors other than textile industry. 